\title{
Lymphocyte Subsets Identified by Monoclonal Antibodies in Healthy Children
}

\author{
YOSHIO YANASE, TOSHIRO TANGO, KO OKUMURA, TOMIO TADA, AND \\ TOMISAKU KAWASAKI \\ Department of Pediatrics, Japanese Red Cross Medical Center /Y.Y., T.K.J; Department of Clinical \\ Epidemiology, Tokyo Metropolitan Institute of Medical Science IT.T]; Department of Immunology, Juntendo \\ University, School of Medicine [K.O.]; and Department of Immunology, Faculty of Medicine, University of Tokyo \\ [T.T], Tokyo, Japan
}

\begin{abstract}
The distributions of lymphocyte subsets and monocytes in the peripheral blood mononuclear leukocytes of 72 normal children from 2 months to $13 \frac{5}{12}$ yr were examined using quantitative immunofluorescence analysis with monoclonal antibodies. Distinct decreases with age were found in the total leukocyte counts, the percentages and the absolute numbers of peripheral blood mononuclear leukocytes. The percentages of Leu- $2 \mathrm{a}^{+}$cells, Leu- $7^{+}$cells, and Leu-M3 ${ }^{+}$cells significantly increased with age, whereas the percentages of $\mathrm{Leu}-3 \mathrm{a}^{+}$cells, Leu- $4^{+}$cells, and $2 \mathrm{H}^{+}$cells significantly decreased with age. As a result, ratios of Leu-3a $\mathrm{a}^{+} /$Leu- $2 \mathrm{a}^{+}$decreased with age. No prominent differences with age were found in the proportions of Leu- $10^{+}$cells and HLA-DR ${ }^{+}$cells. (Pediatr Res 20: 1147-1151, 1986)
\end{abstract}

Abbreviations

PBL, peripheral blood mononuclear leukocyte MEM, minimal essential medium

Since a number of monoclonal antibodies directed against cell surface antigens of human lymphocyte subsets have recently become available, quantitative immunofluorescence analysis with these monoclonal antibodies and flow cytometry techniques has become technically possible $(1,2)$. The application of these monoclonal antibodies to clinical medicine has been providing not only new dimensions to the diagnosis of human diseases but also a new clinical parameter to monitoring therapeutic progress (3).

In proceeding to carry out the study on lymphocyte subsets in various kinds of diseases commonly encountered in childhood, we have noticed that ranges of values of lymphocyte subsets in healthy infants and young children that were examined as normal controls are apparently different from those in young adults and elderly humans previously reported (Yanase Y, Tango T, Okumura $\mathrm{K}$, Tada $\mathrm{T}$, Kawasaki $\mathrm{T}$, unpublished data). Therefore, a more detailed examination was performed to determine the normal percentage of each lymphocyte subset in healthy children. Data from children with diseases can be compared with data from healthy controls.

Received January 17, 1986; accepted June 18, 1986.

Correspondence and reprint requests should be addressed to Yoshio Yanase Department of Pediatrics, Japanese Red Cross Medical Center, 4-1-22, Hiroo, Shibuya-ku, Tokyo 150, Japan.

Supported by grants from the Japan Heart Foundation for 1983 and from the Toyota Foundation for 1984. The authors are grateful to Ms. Y. Matsui for her excellent secretarial help.

\section{PATIENTS, MATERIALS, AND METHODS}

Donors. Seventy-two heparinized venous blood samples were obtained from apparently healthy children attending the Department of Pediatrics, Japanese Red Cross Medical Center at Tokyo from May 1983 to April 1984. The mean age of healthy children was $3.95 \pm 3.18$ (mean $\pm \mathrm{SD}$ ) yr old, ranging from 2 months to $13 \% / 12$ yr of age with a male/female ratio of $42 / 30$.

Monoclonal antibodies. Fluorescein-conjugated monoclonal antibodies, termed Leu-2a, Leu-3a, Leu-4, Leu-7, Leu-10, LeuM3, and HLA-DR were purchased from Becton Dickinson Monoclonal Center (Mountain View, CA). Leu-2a is directed at the suppressor/cytotoxic $T$ cell subset $(2,5-7)$; Leu-3a, at the helper/inducer T cell subset $(2,6,7)$; Leu-4, at total T cells (7); Leu-7, at natural killer/killer cells $(8,9)$; Leu-10, at B cells and activated T cells; Leu-M3, at mature monocytes/macrophages (10); HLA-DR, at B cells, monocytes/macrophages and activated $\mathrm{T}$ cells $(11,12)$; and $2 \mathrm{H} 7$, at B cells (13).

Analysis of stained cells with flow cytometry. Human PBL were prepared by centrifugation of heparinized venous blood on Ficoll-Isopaque (Ficoll-Paque; Pharmacia, Uppsala, Sweden) at room temperature and washed three times in ice cold MEM (eagle MEM; Nissui, Tokyo, Japan). These cells were then stained for $40 \mathrm{~min}$ in microtiter plates on ice by reacting $5 \times 10^{5}$ target cells/well with saturation levels of directly fluorescein-conjugated monoclonal antibodies. Cells were then washed with MEM three times and analyzed immediately using a fluorescence activated cell sorter (FACS-II; Becton-Dickinson, Mountain View, CA). After setting forward light scatter gate on the lymphocyte cluster and monocyte cluster, $1 \times 10^{4}$ cells were analyzed. Immunofluorescence staining with fluorescein-conjugated mouse monoclonal non-specific IgG1, IgG2 and IgM (Becton-Dickinson Monoclonal Center) was used as a negative control. The numbers of cell populations were estimated from fluorescence-positive cells with background cells subtracted, and their proportions were expressed as percentages of the analyzed cells.

Statistical analysis. Studied individuals were divided into four groups: group A (less than $1 \mathrm{yr}, n=15$ ); group B (from 1 to $2^{11 / 12}$ yr, $n=20$ ); group C (from 3 to $4^{11 / 12} \mathrm{yr}, n=14$ ); and group $\mathrm{D}$ (from 5 to $135 / 12$ yr, $n=23$ ).

All the individuals were examined for Leu- $2 \mathrm{a}^{+}$cells, Leu- $3 \mathrm{a}^{+}$ cells, Leu- $4^{+}$cells, Leu- $7^{+}$cells, and Leu- $10^{+}$cells. On the other hand, 65 individuals (group A nine, group B 19, group C 14, and group D 23) for $2 \mathrm{H} 7^{+}$cells, 70 individuals (group A 13 , group B 20, group C 14, and group D 23) for Leu-M3 ${ }^{+}$cells, and 69 individuals (group A 12 , group B 20, group C 14, and group D 23) for HLA-DR ${ }^{+}$cells were examined.

All the values of lymphocyte subsets, monocytes, and the Leu$3 \mathrm{a}^{+} /$Leu- $2 \mathrm{a}^{+}$ratios were expressed as arithmetic mean $\pm 2 \mathrm{SD}$. 
Age-related differences among 4 groups were tested for significance by multiple comparison test using Scheffé's procedure (14). A probability of $<0.05$ was considered significant.

\section{RESULTS}

Age effect. Total Leukocyte and Differential Counts. As shown in Figure 1, remarkable decreases with age were found in the total leukocyte counts, the percentages of PBL and the absolute numbers of PBL among the four age groups.

According to the results of Scheffe's multiple comparison test (Table 1), an almost identical changing pattern was observed in the three items. That is, the youngest age group A had significantly high values as compared with the other three age groups, plus a significant difference in values between group B and group $D$ was observed (pattern a). In the total leukocyte counts, however, there was no significant difference between group A and group B (pattern $\mathrm{a}^{\prime}$ ).

Percentages of Lymphocyte Subsets and Monocytes and Leu$3 a^{+} /$Leu- $2 a^{+}$Ratios. As shown in Figures 2 to 4 , the percentages of Leu- $2 \mathrm{a}^{+}$cells, Leu- $7^{+}$cells, and Leu-M3 ${ }^{+}$cells closely increased in parallel with age, whereas the percentages of Leu- $3 \mathrm{a}^{+}$cells, Leu- $4^{+}$cells, and $2 \mathrm{H}^{+}$cells clearly decreased with age. As a result, the Leu- $3 \mathrm{a}^{+} /$Leu- $2 \mathrm{a}^{+}$ratio markedly decreased with age, while no prominent changes with age were shown in the percentages of Leu- $10^{+}$cells and HLA-DR ${ }^{+}$cells.

According to the results of Scheffe's multiple comparison test (Table 2), three kinds of decreasing patterns with age were observed. In the percentage of Leu- $4^{+}$cells, a significant decrease

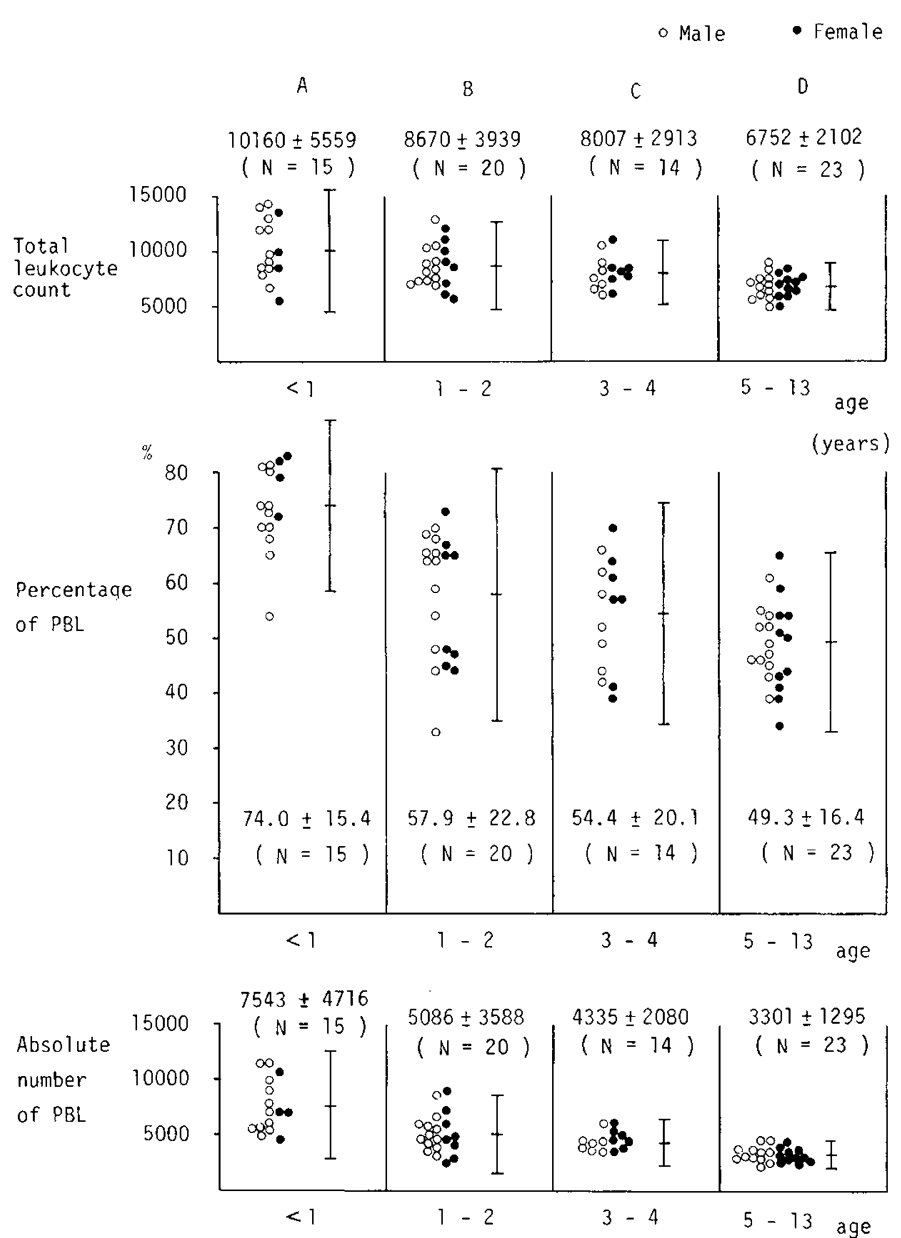

Fig. 1. Total leukocyte counts, percentages of PBL, and absolute numbers of PBL in healthy children. Data are presented as the mean \pm $2 \mathrm{SD}$.
Table 1. Results of Scheffé's multiple comparison test in total leukocyte and differential counts among four age groups

Changing

Comparison of age group A-B A-C A-D B-C B-D C-D pattern

\begin{tabular}{llllll} 
Total leukocyte count & & $*$ & $\dagger$ & $*$ & $\mathrm{a}^{\prime} \searrow$ \\
Percentage of PBL & $\dagger$ & $\dagger$ & $\dagger$ & $*$ & $\mathrm{a} \searrow$ \\
Absolute number of PBL & $\dagger$ & $\dagger$ & $\dagger$ & $\ddagger$ & $\mathrm{a} \searrow$ \\
\hline
\end{tabular}

* Significant difference between two age groups, $p<0.05$.

$\uparrow$ Significant difference between two age groups, $p<0.001$.

$\ddagger$ Significant difference between two age groups, $p<0.01$.
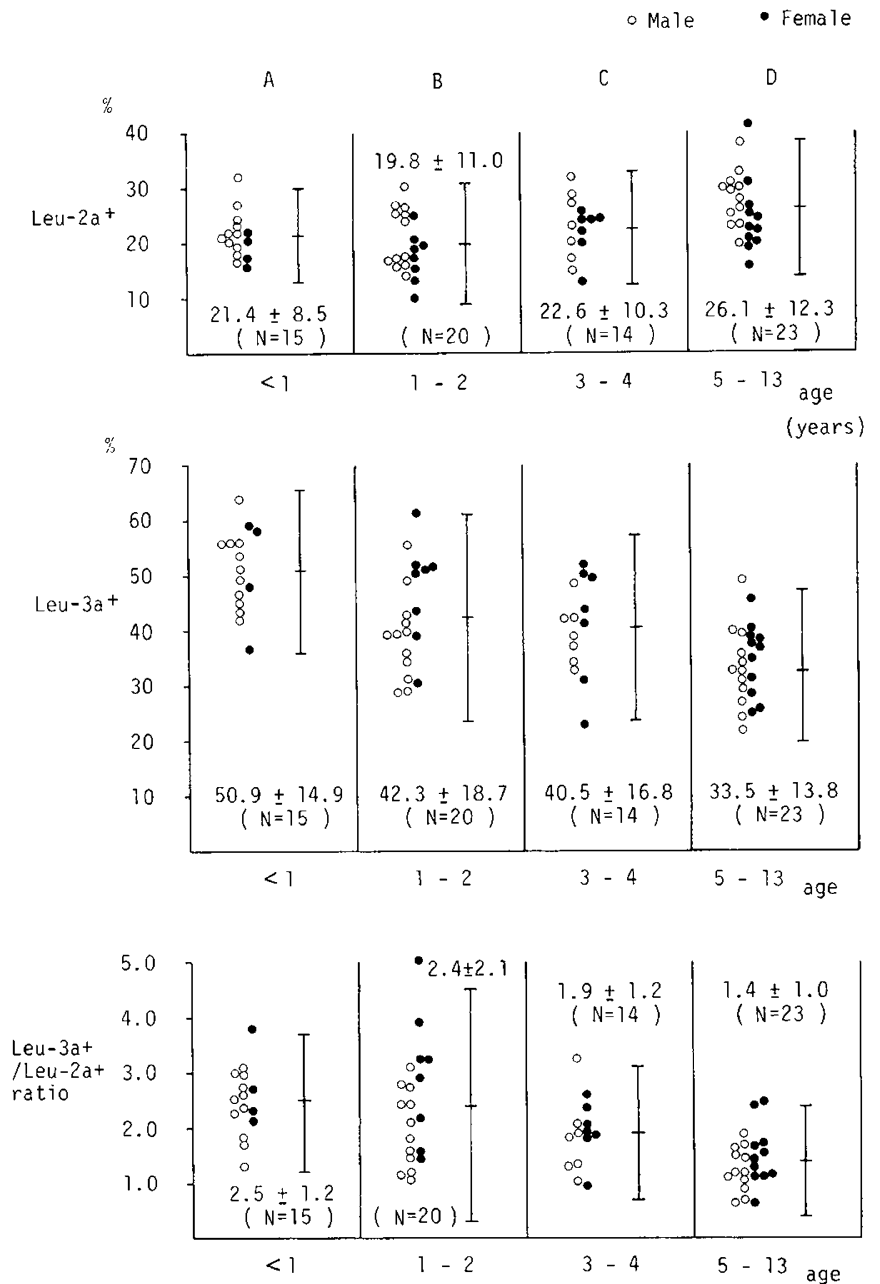

Fig. 2. Percentages of Leu- $2 \mathrm{a}^{+}$cells, Leu- $3 \mathrm{a}^{+}$cells, and Leu- $3 \mathrm{a}^{+} /$Leu$2 \mathrm{a}^{+}$ratios in healthy children. Data are presented as the mean $\pm 2 \mathrm{SD}$.

occurred after the age of $1 \mathrm{yr}$, but no significant difference among the three age groups older than 1 yr was shown (pattern $b$ ). The change in the percentage of Leu- $3 \mathrm{a}^{+}$cells belonged to pattern $\mathrm{a}$. In the ratio of Leu- $3 \mathrm{a}^{+} /$Leu- $2 \mathrm{a}^{+}$and the percentage of $2 \mathrm{H}^{+}$ cells, significant decreases were observed between children less than $3 \mathrm{yr}$ old (group A or B) and older than $5 \mathrm{yr}$ (group D), though there were no significant differences between group $A$ and group B (pattern c). On the other hand, three different kinds of increasing trend with age were seen in the percentages of Leu$2 \mathrm{a}^{+}$cells, Leu- $7^{+}$cells, and Leu-M3 ${ }^{+}$cells.

Absolute Numbers of Lymphocyte Subsets and Monocytes. As shown in Table 3 , distinct decreases with age were observed in the absolute numbers of Leu- $2 \mathrm{a}^{+}$cells, Leu- $3 \mathrm{a}^{+}$cells, Leu- $4^{+}$ cells, Leu- $10^{+}$cells, $2 \mathrm{H}^{+}$cells, and $\mathrm{HLA}^{+} \mathrm{DR}^{+}$cells, whereas no major change with age was indicated in the absolute numbers of Leu- $7^{+}$cells and Leu-M3 ${ }^{+}$cells. 

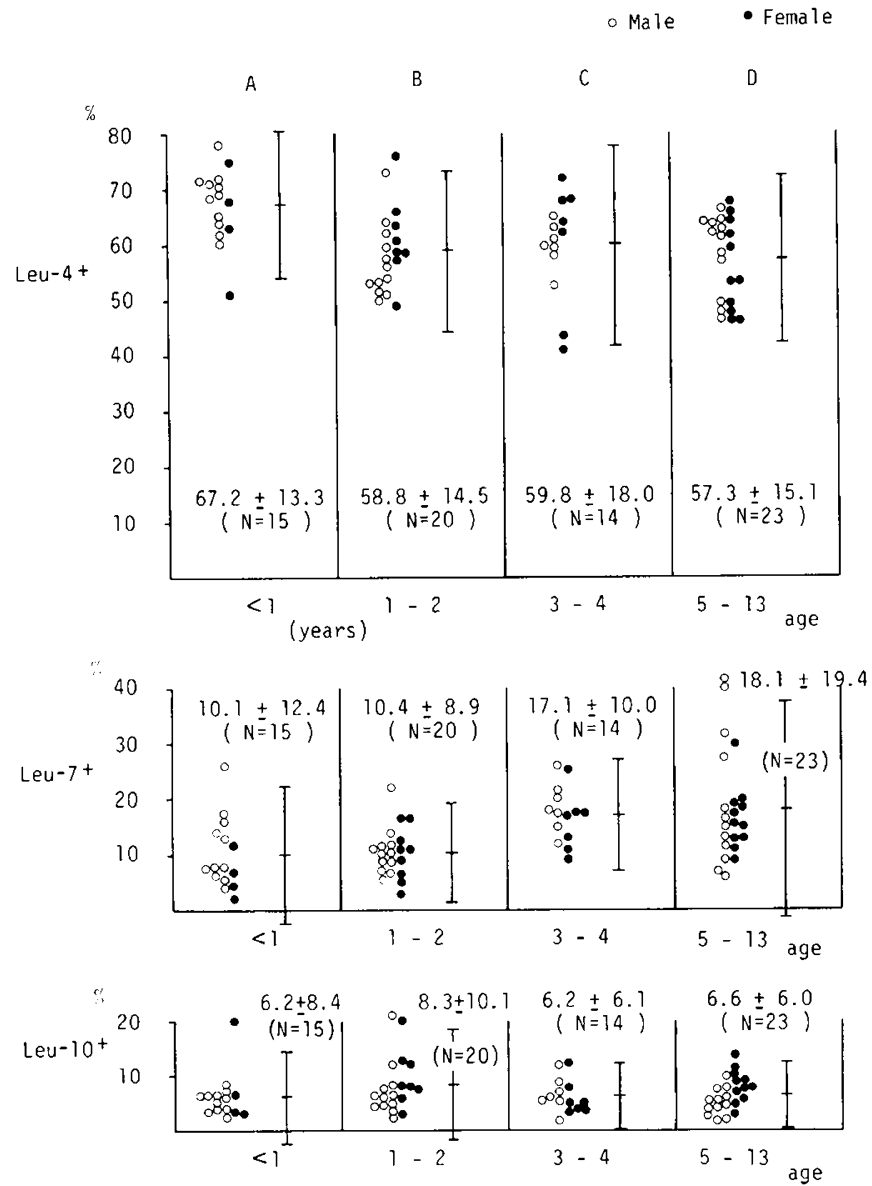

Fig. 3. Percentages of Lcu- $4^{+}$cells, Leu- $7^{+}$cells, and Leu- $10^{+}$cells in healthy children. Data are presented as the mean $\pm 2 \mathrm{SD}$.

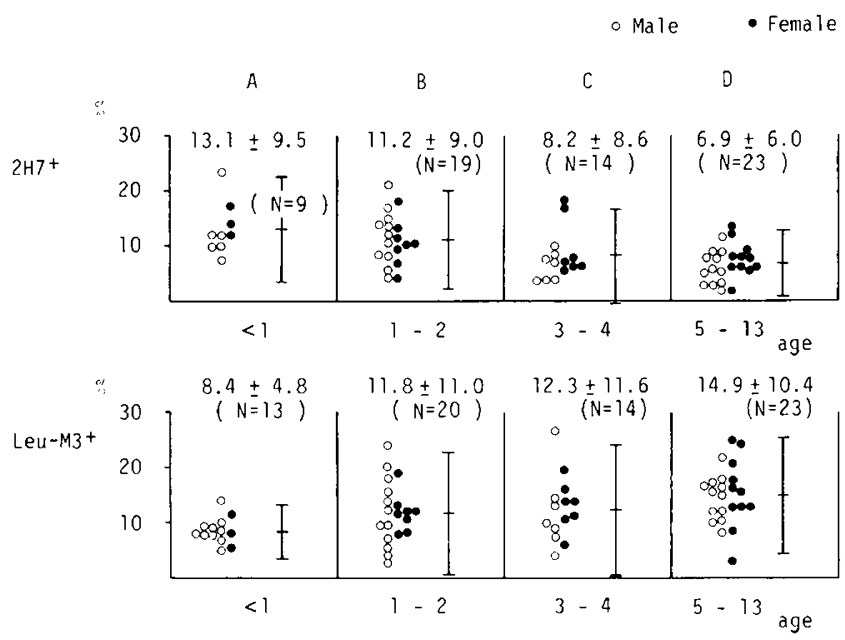

(years)

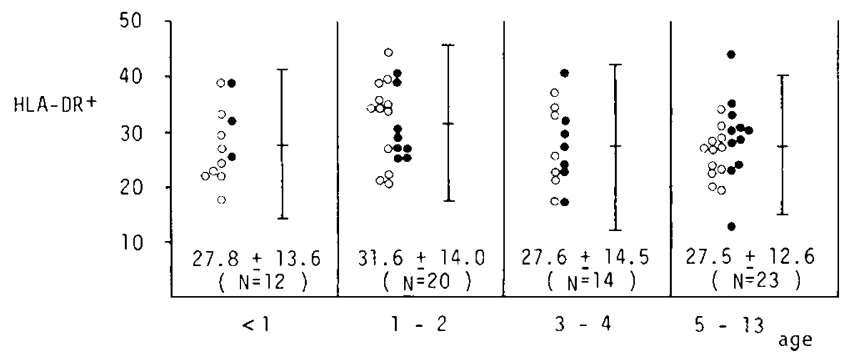

Fig. 4. Percentages of $2 \mathrm{H} 7^{+}$cells, Leu-M $3^{+}$cells, and $\mathrm{HLA}_{-}-\mathrm{DR}^{+}$cells in healthy children. Data are presented as the mean $+2 \mathrm{SD}$.
Table 2. Results of Scheffé's multiple comparison test in percentages of lymphocyte subsets and monocytes, and Leu$3 a^{+} /$Leu- $2 a^{+}$ratios among four age groups

Changing

Comparison of age group A-B A-C A-D B-C B-D C-D pattern

\begin{tabular}{|c|c|c|c|c|}
\hline Percentage of Leu- $2 a^{+}$cells & & & & * \\
\hline Percentage of Leu- $3 a^{+}$cells & $\dagger$ & $\dagger$ & $\ddagger$ & * \\
\hline Leu- $3 a^{+} /$Leu- $2 a^{+}$ratio & & & $\ddagger$ & $\ddagger$ \\
\hline Percentage of Leu- $4^{+}$cells & & $\dagger$ & $\ddagger$ & \\
\hline Percentage of Leu- $7^{+}$cells & & & $\dagger$ & * \\
\hline Percentage of Leu- $10^{+}$cells & & & & \\
\hline Percentage of $2 \mathrm{H}^{+}$cells & & & * & $\dagger$ \\
\hline Percentage of Leu-M3 ${ }^{+}$cells & & & * & \\
\hline
\end{tabular}

Percentage of HLA-DR ${ }^{+}$

cells

* Significant difference between two age groups, $p<0.01$.

$\dagger$ Significant difference between two age groups, $p<0.05$.

$\ddagger$ Significant difference between two age groups, $p<0.001$.

The results of Scheffé's multiple comparison test were expressed in Table 4. The changing pattern in the absolute number of Leu- $2 \mathrm{a}^{+}$cells belonged to pattern $\mathrm{b}$. Changing patterns in the absolute numbers of Leu- $3 \mathrm{a}^{+}$cells, Leu- $4^{+}$cells, $2 \mathrm{H}^{+}$cells, and $\mathrm{HLA}^{-\mathrm{DR}^{+}}$cells were consistent with pattern a. The absolute number of Leu- $10^{+}$cells changed as pattern $\mathrm{c}$.

Sex effects. No significant differences which could be attributed to sex were shown in the total leukocyte counts, the percentages, and the absolute numbers of PBL as well as of lymphocyte subsets and monocytes, or the Leu- $3 \mathrm{a}^{+} / \mathrm{Leu}-2 \mathrm{a}^{+}$ratios.

\section{DISCUSSION}

In the present study we demonstrated that the total leukocyte counts, the percentages, and the absolute numbers of PBL prominently decreased with age. In childhood the alterations of the normal total and differential leukocyte counts with age have already been established $(15,16)$, and our results are in agreement.

Age-related changes in cell-mediated and humoral immunity have progressively been studied during the normal aging of experimental animals and humans (17), but there are few studies on the effects of age on the lymphocyte subsets in childhood. No consistent observations of the aging of human lymphocyte subpopulations, i.e the $T$ cell subpopulation identified by the sheep red blood cell rosette forming method and the B cell subpopulation identified by the cell surface immunoglobulin analysis method have been reported (18-24). The reasons for the discrepancies in the reported proportional and absolute number alterations of $\mathrm{T}$ and $\mathrm{B}$ cell subpopulations with age reported are suggested to be due to technical differences, gender differences, and age classification (25).

With regard to exclusion of the technical differences, recent development of the application of monoclonal antibodies and flow cytometry methods allows us to obtain more precisely analyzed data. Consistent with our results, Yachie et al. (26) reported that the proportion of OKT4 ${ }^{+}$(helper/inducer T) cells was high and the proportion of $\mathrm{OKT}^{+}$(suppressor/cytotoxic $\mathrm{T}$ ) cells was low in cord blood $\mathrm{T}$ cells as compared with in normal adults, and $\mathrm{OKT} 4^{+} / \mathrm{OKT} 8^{+}$ratios decreased with age and reached near adult levels around 3 to $5 \mathrm{yr}$ of life. The results of this study were also consistent with a study by Abo et al. (9) in which it was shown that there was a progressive increase with age in the proportion of $\mathrm{HNK}-\mathrm{I}^{+}\left(\mathrm{Leu}-7^{+}\right)$cells.

The prominent decrease of $\mathrm{B}\left(2 \mathrm{H} 7^{+}\right)$cells and the increase of monocytes (Leu-M $3^{+}$cells) with age was demonstrated, although we could not find the relationship between the functional alteration with age and these changes in this study. However, in adulthood there are various reports regarding the effect of age on 
Table 3. Age-dependent differences in absolute numbers of lymphocyte subsets and monocytes among four age groups*

\begin{tabular}{|c|c|c|c|c|}
\hline $\begin{array}{l}\text { Age group } \\
\text { Age }(\mathrm{yr}) \\
(n)\end{array}$ & $\begin{array}{c}\text { A } \\
<1(15) \\
\end{array}$ & $\begin{array}{c}\mathrm{B} \\
1-2(20) \\
\end{array}$ & $\begin{array}{c}C \\
3-4(14)\end{array}$ & $\begin{array}{c}\mathrm{D} \\
5-13(23)\end{array}$ \\
\hline Leu- $2 \mathrm{a}^{+}$cells & $1614 \pm 1131$ & $1019 \pm 990$ & $1003 \pm 779$ & $865 \pm 530$ \\
\hline Leu- $3 \mathrm{a}^{+}$cells & $3817 \pm 2570$ & $2094 \pm 1527$ & $1798 \pm 1372$ & $1104 \pm 616$ \\
\hline Leu- $4^{+}$cells & $5026 \pm 2996$ & $2971 \pm 2188$ & $2641 \pm 1739$ & $1890 \pm 872$ \\
\hline Leu- $7^{+}$cells & $852 \pm 1517$ & $531 \pm 704$ & $717 \pm 408$ & $599 \pm 649$ \\
\hline Leu- $10^{+}$cells & $447 \pm 478$ & $443 \pm 707$ & $256 \pm 226$ & $219 \pm 235$ \\
\hline $2 \mathrm{H} 7^{+}$cells $\dagger$ & $1149 \pm 1278$ & $591 \pm 811$ & $362 \pm 476$ & $233 \pm 242$ \\
\hline Leu-M3+ cells $\ddagger$ & $672 \pm 667$ & $590 \pm 645$ & $532 \pm 530$ & $485 \pm 369$ \\
\hline HLA-DR $^{+}$cells $\S$ & $2337 \pm 2266$ & $1625 \pm 1363$ & $1189 \pm 784$ & $910 \pm 556$ \\
\hline
\end{tabular}

$*$ Mean $\pm 2 \mathrm{SD}$

$\dagger$ The number of subjects was 65 (A, nine; B, 19; C, 14; and D, 23).

$\ddagger$ The number of subjects was $70(\mathrm{~A}, 13 ; \mathrm{B}, 20 ; \mathrm{C}, 14$; and $\mathrm{D}, 23)$.

$\S$ The number of subjects was $69(\mathrm{~A}, 12 ; \mathrm{B}, 20 ; \mathrm{C}, 14$; and $\mathrm{D}, 23)$.

Table 4. Results of Scheffé's multiple comparison test in absolute numbers of lymphocyte subsets and monocytes among four age groups

\begin{tabular}{|c|c|c|c|c|c|}
\hline Comparison of age group & A-B & $\mathrm{A}-\mathrm{C}$ & $A-D$ & B-C B-D C-D & $\begin{array}{l}\text { Changing } \\
\text { pattern }\end{array}$ \\
\hline Absolute no. of Leu- $2 \mathrm{a}^{+}$cells & $*$ & $*$ & $\dagger$ & & $b \searrow$ \\
\hline Absolute no. of Leu- $3 \mathrm{a}^{+}$cells & $\dagger$ & $\dagger$ & $\dagger$ & $*$ & $a \searrow$ \\
\hline $\begin{array}{l}\text { Absolute no. of Leu- } 4^{+} \text {cells } \\
\text { Absolute no. of Leu- } 7^{+} \text {cells }\end{array}$ & $\dagger$ & $\dagger$ & $t$ & $*$ & $a \searrow$ \\
\hline Absolute no. of Leu- $10^{+}$cells & & & $\ddagger$ & $\ddagger$ & $c \searrow$ \\
\hline $\begin{array}{l}\text { Absolute no. of } 2 \mathrm{H}^{+} \text {cells } \\
\text { Absolute no. of Leu-M3 } 3^{+} \text {cells }\end{array}$ & $*$ & $\dagger$ & $\dagger$ & $f$ & $a \searrow$ \\
\hline Absolute no. of HLA-DR ${ }^{+}$cells & $\ddagger$ & $\dagger$ & $\dagger$ & $*$ & $\mathrm{a} \searrow$ \\
\hline
\end{tabular}

* Significant difference between two age groups, $p<0.01$.

$\dagger$ Significant difference between two age groups, $p<0.001$.

$\$$ Significant difference between two age groups, $p<0.05$.

T cell subpopulations identified by monoclonal antibodies (2730 ), although the reason for the differences shown of in these results is unknown.

Regarding values of normal adults in our laboratory, no significant differences in the values of any of the lymphocyte subsets and monocytes examined between young adults (from 18 to 29 yr) and group D (from 5 to $135 / 12$ yr) were observed (data not shown). In addition, the levels of the lymphocyte subsets and monocytes of children more than $3 \mathrm{yr}$ of age were considered to be consistent with those of young adults, since no significant differences in the values of any of the lymphocyte subsets and monocytes examined between group B (from 1 to $2^{11 / 12} \mathrm{yr}$ ) and group $C$ (from 3 to $4^{11 / 12} \mathrm{yr}$ ) or between group $C$ and $D$ were shown, and the differences between group $B$ and $D$ were seen to be significant for most items in our results.

In order to evaluate diseases in children which may be associated with immunoregulatory changes, it is extremely important to determine the normal ranges of lymphocyte and monocyte subpopulations. PBL from individuals classified according to age must be analyzed using well-established and more specific methods. Therefore, it is essentially important for each individual laboratory to establish its own individual age-related normal reference ranges.

Acknowledgments. The authors are grateful to Ms. Y. Matsui for excellent secretarial help. A fluorescein-conjugated monoclonal antibody termed $2 \mathrm{H} 7$ was kindly provided by Dr. J. A. Ledbetter, Genetic Systems Corporation, Seattle, WA.

\section{REFERENCES}

1. Kung PC, Goldstein G, Reinherz EL, Schlossman SF 1979 Monoclonal antibodies defining distinctive human $T$ cell surface antigens. Science 206:347349

2. Ledbetter JA, Evans RL, Lipinski M, Cunningham-Rundles C, Good RA, Herzenberg LA 1981 Evolutionary conservation of surface molecules that distinguish $\mathrm{T}$ lympocyte helper/inducer and cytotoxic/suppressor subpopulations in mouse and man. J Exp Med 153:310-323

3. Goldstein G, Lifter J, Mittler R 1982 Immunoregulatory changes in human disease detected by monoclonal antibodies to $\mathrm{T}$ lymphocytes. In: McMichael AJ, Fabre JM (eds) Monoclonal Antibodies in Clinical Medicine. Academic Press, London, pp 54-70

4. Deleted in proof.

5. Engleman EG, Benike CJ, Evans RL 1981 Circulating antigen-specific suppressor $\mathrm{T}$ cells in a healthy woman: mechanism of action and isolation with a monoclonal antibody. Clin Res 29:365A

6. Engleman EG, Benike CJ, Glickman E, Evans RL 1981 Antibodies to membrane structures that distinguish suppressor/cytotoxic and helper T lymphocyte subpopulations block the mixed leukocyte reaction in man. J Exp Med 154:193-198

7. Kotzin BL, Benike CJ, Engleman EC 1981 Introduction of immunoglobulinsecreting cells in the allogeneic mixed leukocyte reaction: regulation by helper and suppressor lymphocyte subsets in man. $\mathrm{J}$ Immunol 127:931-935

8. Abo T, Balch CM 1981 A differentiation antigen of human NK and K cells identified by monoclonal antibody (HNK-1) J Immunol 127:1024-1029

9. Abo T, Cooper MD, Balch CM 1982 Postnatal expansion of the natural killer and killer cell populations in humans identified by the monoclonal NHK-1 antibody. J Exp Med 155:321-326

10. Dimitriu-Bona A, Burmester GR, Water SJ, Winchester RJ 1983 Human monoclonal phagocyte differentiation antigens: 1. Patterns of antigenic expression on the surface of human monocytes and macrophages defined by monoclonal antibodies. J Immunol 130:145-151

11. Lampson LA, Levy R 1980 Two populations of Ia-like molecules on a human B cell line. J Immunol 125:293-299

12. Wanke R, Miller R, Grogan T, Pederson M, Dilley J, Levy R 1980 Immunologic phenotype in 30 patients with diffuse large-cell lymphoma. $N$ Engl $J$ Med 303:293-300

13. Clark EA, Yokochi T 1984 Human B cell and B cell blast-associated surface molecules defined with monoclonal antibodies. In: Bernard A, Boumsell L, Dausset J, Milstein C, Schlossman SF (eds) Leucocyte typing. Springer Verlag, Berlin, pp 339-346

14. Scheffé H 1959 The analysis of variance. John Wiley \& Sons Inc., New York, pp 55-89

15. Mackinney AAJr 1978 Effect of aging on the peripheral blood lymphocyte count. J Gerontol 33:213-216

16. Williams WJ 1983 Heamatology in the aged. In: Williams WJ, Beutler E, Erslev AV, Lichtman MA (eds) Hematology. McGraw-Hill, New York, pp 47-48

17. Makinodan T, Kay MB 1980 Age influence on the immune system. In: Kunke HG, Dixon FJ (eds) Advances in Immunology, Vol 29. Academic Press, New York, pp 287-330

18. Weksler ME, Hutteroth TH 1974 Impaired lymphocyte function in aged humans. J Clin Invest 53:99-104

19. Gupta S, Good RA 1979 Subpopulations of human T lymphocytes X. Alteration in $T, B$, third population cells, and $T$ cells with receptors for immunoglobulin $\mathrm{M}(\mathrm{T} \mu)$ or $\mathrm{G}(\mathrm{T} \gamma)$ in aging humans. J Immunol 122:1214-1219

20. Carosella ED, Mochanko K, Braun M 1974 Rosette-forming T cells in human peripheral blood at different ages. Cell Immunol 12:323-325

21. Weiner HL, Scribner DJ, Schocket AL, Moorhead JW 1978 Increased proliferative response of human peripheral blood lymphocytes to anti-immunoglobulin antibodies in elderly people. Clin Immunol Immunopathol 9:356362

22. Augener W, Cohnen G, Reuter A, Brittinger G 1974 Decrease of T lymphocyte during aging. Lancet 1:1164

23. Hallgren HM, Kersey JH, Dubey DP, Yunis EJ 1978 Lymphocyte subsets and integrated immune function in aging humans. Clin Immunol Immunopatho $10: 65-78$ 
24. Falcao RP 1980 Human blood lymphocyte subpopulations from birth to eight years. Clin Exp Immunol 39:203-207

25. Mascart-Lemone F. Delespesse G, Servais G, Kunstler M 1982 Characterization of immunoregulatory $\mathrm{T}$ lymphocytes during ageing by monoclonal antibodies. Clin Exp Immunol 48:148-154

26. Yachie A, Miyawaki T, Nagaoki T, Yokoi T, Mukai M, Uwadana N, Taniguchi N 1981 Regulation of B cell differentiation by $\mathrm{T}$ cell subsets defined with monoclonal OKT4 and OKT8 antibodies in human cord blood. J Immunol 127:1314-1317

27. Moody CE. Innes JB, Staiano-Coico L, Incefy GS, Thaler HT, Weksler ME 1981 Lymphocyte transformation induced by autologous cells. XI. The effect of age on the autologous mixed lymphocyte reaction. Immunology 44:431438

28. Schwab R, Staiano-Coico L, Weksler ME 1983 Immunological studies of aging IX. Quantitative differences in T lymphocyte subsets in young and old individuals. Diag Immunol 1:195-198

29. Nagel JE, Chrest FJ, Adler WH 1981 Enumeration of T lymphocyte subsets by monoclonal antibodies in young and aged humans. J Immunol 127:20862088

30. Bongers V, Bertrams $J 1984$ The influence of common variables on $T$ cell subset analysis by monoclonal antibodies. J Immunol Methods 67:243-253

\title{
Announcements
}

\author{
Annual Meeting
}

The American Pediatric Society and The Society for Pediatric Research announce the abstract deadline for the 1987 Annual Meeting (April 27-May 1, Disneyland Hotel, Anaheim, CA) has been set as December 3, 1986.

For further information contact: SPT-Debbie L. Wogenrich, The Society for Pediatric Research, Department of Pediatrics, UNM School of Medicine, Albuquerque, NM 87131, (505) 277-6629 or APS-Dr. Audrey K. Brown, Secreatry-Treasurer, Department of Pediatrics, Box 49, SUNY, Health Sciences Center at Brooklyn, 450 Clarkson Avenue, Brooklyn, NY 11203, (718) $270-1692$.

\section{Pediatric Symposium}

The IIIrd International Symposium on Pediatric Surgical and Neonatal Intensive Care will be held September 15-18, 1987 at the Hotel Sofitel, Paris.

Congress President: G. Huault. President Organizing Committee: F. Beaufils. President Scientific Committee: M. Dehan.

Information: SOCFI-14, Rue Mandar-75002, Paris, France.

\section{9th Summer Program in Methods of Immunologic Research and Diagnosis}

This program is offered by the Ernest Witebsky Center for Immunology, University at Buffalo, State University of New York, June $7-20,1987$. It is a 2 -wk program that consists of combinations of core and elective lectures, demonstrations, discussions, and practical laboratory exercises; participants personally carry out techniques at the bench. Open to postdoctoral level, supervisory senior technologists, and graduate students beyond the master's level.

For detailed program description contact James F. Mohn, M.D., Director, The Ernest Witebsky Center for Immunology, 210 Sherman Hall, Buffalo, New York 14214. (716) 831-2848. Inquiries should be received by 20 February 1987, to insure consideration for acceptance.

\section{Pediatric Respiratory Disease}

The National Heart, Lung, and Blood Institute, National Institutes of Health, has recently published an evaluation report on Pediatric Respiratory Disorders. This report relates to major advancements made in six categories of pediatric respiratory disorders and includes assessment of opportunities and needs in the epidemiology, diagnosis, management, and prevention of pediatric lung diseases. Copies of this report are available on request. Send reprint requests to Pushpa V. Thadani, Ph.D., Structure and Function Branch, DLD, NHLBI, Westwood Building, Room 6A07, Bethesda, MD 20892. 